Environment Conservation Journal 16 (SE) 223-229, 2015

ISSN 0972-3099 (Print) 2278-5124 (Online)

Abstracted and Indexed

\title{
A Symbolic Deconstructed Colonialism in E. M. Forster's A Passage to India
}

\section{Monireh Arvin}

Received: 29.06 .201

\author{
Revised: 10.07.2015
}

Accepted: 15.10.2015

\begin{abstract}
Unlike the title of the novel, A Passage to India, which is an allusion to one of Walt Whitman's poems, here we see the disillusionment of Romanticism. Novel depicts "everything exists, but nothing has values" (Forster, 1985, p.147), the same as the dark discovery in the Marabar Caves. The novel suggests that we must have a passage through the national barriers, and all human beings should become one nation. However, up to end of the novel, we see each time such possibility of oneness is admitted, but due to the so-called deficiencies or malfunctions of the Indians it is immediately denied; the novel leaves us frustrated that such a unity is never established completely. Despite Walt Whitman's view, this passage through the national barriers is not possible. The present study aims to depict a symbolic deconstructed colonialism on Forster's A Passage to India. As a result, the most important question which was posed at the very beginning of the novel, "Can the English and the Indians become friends or not?" is not answered clearly. Each time we begin to admit an opportunity of integration and unity, this chance is immediately delayed or harshly denied. The novel implicitly depicts the three phases of the Hegelian paradigm: thesis, anti-thesis, and synthesis.
\end{abstract}

Keywords: Colonialism; Deconstruction; E. M. Forster; Orients; Symbol

\section{Introduction}

A Passage to India not only depicts a real physical travelling, but it is also a psychological colonial passage. There are so many philosophical, psychological, religious, social, and ethical symbols and elements throughout the novel. This novel could be studied from different viewpoints, as well: spiritual, political, traditional Victorian, religious, symbolic or nihilistic, but the present study tends to examine the pessimistic atmosphere and ineffectual struggling of the novel to develop a relationship between the English and the Indians. The novel demonstrates the period after the World War I, when India was under England's control, but not sooner than the Post-War II, could India get its independency. According to Rama Kundu,

The British writer was willy-nilly part of an imperial society, and the vast empire of India eventually came to manifest before his imagination realms of possibility fantasy, wish-fulfillment, as well as of banishment, unlawful practice, disgrace; an unreadable sign, an incomprehensible area, and and thus an epitome of fearful mystery, threatening and never to be trusted (2008, p.32).Colonization always hides its true objective behind the mask of bringing knowledge and civilization to the

\section{Author's Address}

Department of English, Alborz Campus, University of Tehran, Iran

E-mail: smz_1_mm@yahoo.com colonized race. The novel shows how India cripplingly paves this way towards its independency via the inadequate reactions of the Indians against the English control. Throughout the history, the Indians like the other colonized nations tried at any cost to fulfill their dreams of independency. Nevertheless, the novel through a pessimistic view, a historical unease, and a spiritual vacancy implies that the world is not made for them, and the orients all are doomed to suffer fear, disturbance, and confusion.

\section{THE POSSIBILITY OF UNITY, THESIS}

\section{A. MOSQUE}

The novel is divided into three parts, three Indian seasons - the cold, the hot, and the rains - which include the important religious and symbolic elements. The first part begins with the concept of a mosque, overarching sky, and a party (the Bridge Party), that have something in common, the notion of a bridge or a dome, representing the possibility of oneness and unity. The first meeting between Dr. Aziz and Mrs. Moore was in a mosque. While having some differences between them, both Dr. Aziz and Mrs. Moore have a lot in common: both are sensitive, religious, married twice, and they have two sons and one daughter. By giving us this personal information, the novel tends to emphasize the concept of unity via their first meeting in a mosque, a symbol of oneness. However, in the 
mosque, an ambiguous triumph of Islam is implied in the form of ironic duality of colors. In chapter two, we see one part of the mosque is in black and the other part is in white. There is a hint of communication, but it is accompanied by uncertainty. The white part is the foreshadowing of a half-hearted renewal of friendship between Dr. Aziz and Mr. Fielding near to the end of the novel, and the black part represents the collapse of communication in the part two, the Caves.

\section{B. THE BRIDGE PARTY}

As its name signifies, the Bridge Party was meant to connect the different nations, and to remove the gulf between the Indians and the English. However, ironically, this party is used to expand this gulf by intensifying the hierarchy between them. Through this party, the English could show their superiority and domination towards the Indians, and the novel depicts the deficiency of communication between the two nations. "The Club moved slowly; it still declared that few Mohammedans and no Hindus would eat at an Englishman's table and that all Indian ladies were in impenetrable purdah ..." (Forster, 1985, p. 83). Although some of the Indians knew English, they could not communicate with the English. The majority of the English did not trust the Indians. Mrs. Turton at the Bridge Party, on finding that some guests could speak English and had been to Europe, shrinks: "Her manner had grown more distant since she had discovered that some of the group was westernized, and might apply her own standards to her" (Forster, 1985, p.61). In several occasions, she tells Mrs. Moore that she is superior to everyone in India. The Indians, especially the elite, are reasonably puzzled and embittered by this approach. Mrs. Turton wonders at the Bridge Party, "Why they come at all I don't know. They hate it as much as we do" (ibid). Jajja in his article states, The Indians even the educated ones are shown as desperate to please their British Masters. Dr. Aziz wrenches off his golden collar stud to supply the same to Fielding. In spite of the mimicry and imitation on the part of educated Indians; they are still not accepted as fit and suitable to dine at an English man's table. The British are shown especially hating the Indians with modern ideas (2013, p.42). Ronny calls Dr. Aziz as "the spoilt westernized type", in other words, "a mimic man" (Jajja, 2013, p.43). Ronny's presence in the party was like an intrusion. He portrays the
Anglo-Indian view of the world. He ignores the Indians, and his behavior is ill-mannered. His arrival changes the pleasant and friendly party atmosphere to an annoying and irritable one. Still the novel justifies his manner by this excuse that possibly his behavior is not his own fault, but rather it is because of the dehumanizing power of his position.

\section{GAP}

E. M. Forster is keenly and painfully aware of the gap that "constituted the reality of his contemporary imperialistic situation". As Edward Said wonders, "What are the cultural grounds on which both natives and liberal Europeans lived and understood each other? How much could they grant each other? How, within the circle of imperial domination, could they deal with each other before radical change occurred?" (Said, 1994, p. 241, as cited in Kundu, 2008, p. 33). Kundu in his article argues, "Mr. Turton, the Collector, represents another typical stance of British 'officialism' in his emphasis on maintaining a studied distance from 'India' and 'Indians"' (2008, pp.35-36). "I have never known anything but disaster result when English people and Indians attempt to be intimate socially. Intercourse, yes. Courtesy, by all means. Intimacy - never, never" (Forster, 1985, pp.173174). The English do not approve of any intimacy between themselves and the Indians. In the Club "those who knew that Fielding had undertaken to accompany them [the picnic team to Marabar], and missed the early train were sorry for him; it was what is to be expected when a man mixes himself up with the natives; always ends in some indignity" (Forster, 1985, p.193). Mc Bryde's theory of the climatic zones emphasizes the existing gap between these two opposite nations: "All unfortunate natives are criminals at heart, for the simple reason that they live south of latitude 30 . They are not to blame, they have not a dog's chance - we should be like them if we settled here" (Forster, 1985, p.176). From the very beginning of the novel, we see a big gulf in the description of the city, Chandrapore. The part visited by the English is "a city of gardens" (Forster, 1985, p.9), but the other parts where Indians live, especially around the River Ganges, are full of filth. This physical gap represents a separation and the concept of racial discrimination, the Anglo-Indian Colonial relationship against the ancient Indians, from which the Indians can never 
escape. "The gap can be only briefly bridged at rare moment, but it is only a transitory affair. In spite of their great mutual affection, Dr. Aziz is eventually alienated from Mr. Fielding because of an unfounded suspicion which rises", according to Kundu, "from a deeper gap" (2008, p.37): Suspicion in the Oriental is a sort of malignant tumor, a mental malady, that makes him selfconscious and unfriendly suddenly; he trusts and mistrusts at the same time in a way the Westerner cannot comprehend. It is his demon, as the Westerner's is hypocrisy. Aziz was seized by it, and his fancy built a satanic castle (Forster, 1985, p.276).The word "nothing" is repeated a lot all throughout the first chapter, and it foreshadows the concept of impossibility and nihilism from the beginning of the novel. Colonization is the central theme of the novel. The majority of the English through their cold, harsh, and disrespectful behavior try to colonize the Indians. The notion of separation runs through the novel. Adela Quested, Ronny's fiancée, has taken this passage to India to marry her fiancé, but when she sees there is a big gap between her mentality and Ronny's, she changes her idea of the marriage. Mrs. Moore, as a symbol of a reconciling power between two nations, cannot accept her son's political and dehumanized notions, and when she dies at the end of this passage, this gulf is deepened and again the possibility of oneness is denied.

\section{D.HESITATIONS， PROCRASTINATIONS, HYPOCRISY}

According to Raman Kundu, the British author is "a part of an imperial society" and the Indian crowd often seemed to him "inscrutable, malign, lacking moral integrity and individual will" (2008, p.34). E. M. Forster, as an English author, depicts the Indians as the children of nature, polite, affectionate, eager to imitate, kind, and at the same time wayward, and double-dealing people. According to the writer, the Indians are the hypocritical and indecisive people. Forster applies a lot of symbols and hints to demonstrate the deficiencies of the Indians in judgments, decisions, and distinctions. Kundu argues that the Indians represent to the outsider "an unreadable sign, an incomprehensible area and thus an epitome of fearful mystery, threatening and never to be trusted" (ibid). Dr. Aziz's boss, Major Callendar, "never realized that the educated Indians visited one another constantly. He only knew that no one ever told him the truth, although he had been in the country for twenty years" (Forster, 1985, p.27). Thus, "the element of mistrust", according to Kundu, "is so strong and pervasive that it can be easily and quickly fanned into a fanatic hatred" (2008, p.35). Forster can barely hide his sarcasm towards the herd psychosis as he comments: Nothing enrages Anglo-India more than the lantern of reason if it is exhibited for one moment after its extinction is decreed. All over Chandrapore that day the Europeans were putting aside their normal personalities and sinking themselves in their community. Pity, wrath, heroism, filled them, but the power of putting two and two together was annihilated (Forster, 1985, p.175).Dr. Aziz in response to Hamidullah Begam who called him for the second marriage said that one marriage was enough and he postponed the next one for later. It represents that the Indians delay everything for later; that is the reason why they cannot have unity and independency. A group of educated people think this friendship between the English and the Indians is possible, but Forster implies that Indians have no plan for their unity, and independency. While speaking of a simple stamp album or marriage, they reach to the other issues. Therefore, they do not have any consistency and unified plan; they cannot reach to their independency.

Ramanujan in his article, "Is there an Indian way of thinking?" praises the Indians for "not being hung up on an objectivity that distinguishes self from non-self, interior from exterior." This trait signifying their "inconsistency and the apparent inability to distinguish self and non-self" is repeated in several occasions (Ramanujan, 1989, p.45). Mrs. Moore found a wasp on a peg inside her room. The insect did not distinguish a tree from a peg. This simple example represents that Forster takes the majority of the Indians as the animals, unable to make a sharp or tidy distinction between the main and the trivial issues.Going to hang up her cloak, she found the tip of the peg was occupied by a small wasp. She had known this wasp or his relatives by song; they were not as English wasps, but had long yellow legs which hung down behind when they flew. Perhaps he mistook the peg for a branch - no Indian animal has any sense of an interior. Bats; rats, birds, insects will as soon nest 
inside the house as out, it is to them a normal growth of the eternal jungle, which alternately produces houses, trees, houses, trees. There he clung, asleep, while jackals bayed their desires and mingled with the percussion of drums (Forster, 1985 , p.35).The narrator in the novel, as Mohammad Ayub Jajja argues, describes India "as an eternal jungle infested with rats, bats, wasps and jackals without any discrimination of home or forest" (2013, p.41). Each of these animal names symbolically degrades the Indians' human positions to the lowest level of dehumanized or half-human situations. In chapter ten, different animals make noise, representing that it does not matter how India is governed. The majority of the Indians, like these animals, do not care whether India is ruled by England or by India itself. "It matters so little to the majority of living beings what the minority, that calls itself human, desires of decides. Most of the inhabitants of India do not mind how India is governed" (Forster, 1985, p.111).Unlike the industrialized society of England, the Indians are close to nature. However, the novel takes this cultural difference between the nations (English, Indians) as a barbaric and animal-like aspect of an orient's personality. Perchance, as Moosavinia explains, Forster tends to mingle some degrees of sense of humor in his symbolic novel by depicting "the Indians as child-like, irrational, untrustworthy, and comic" (2011, p.74).To Forster the Indians lack a sound and consolidated personality. The narrative voice in the novel, as S. R. Moosavinia argues in his article, "Texts and Politics: Postcolonial Revaluations of two British Classics", treats the Oriental as an inferior being. "The Oriental tells lies, takes commission, is accustomed to disorder, and has no sense of time" (Moosavinia, 2011, p.69). Dr. Aziz, as his name runs through $\mathrm{A}$ to $\mathrm{Z}$, is a mercury character, and he shows a changeable or better to say a round personality; at first he respects the English, but little by little, he changes his mind and becomes disrespectful to them. Forster in different occasions mentions the hypocrisy of the Indians. The same trait is criticized by Ramanujan when he states that "They all seemed to agree on one thing: the Indian trait of hypocrisy. Indians do not mean what they say, and say different things at different times (1989, p.44). When Mrs. Moore politely asked Mrs. Bhattacharya to call on her some convenient day, she accepted to do so, but not honestly. In another occasion, when Dr. Aziz invited Mr. Fielding to his home, after a while he changed his idea, and asked him to meet one another in the Caves. Gradually, to compensate his hesitation, Dr. Aziz asked Mr. Fielding to come to his untidy house, and unlike his religious belief showed his wife's photo to Mr. Fielding. To Forster, generally, the Indians pretend to be polite, friends to the English, and hospitable at any expense, but indeed they have hypocrisy in their behaviors. They do not keep their promises, nor do they trust even in themselves, let alone the English. Still, they struggle to fuse and unite with the English, but such unity or fusion is postponed and denied through the novel. This denial of unity also is expanded among the English, as we see Adela Quested cannot reunite with her fiancé, and Mrs. Moore develops an obvious religious and moral conflict with his son. Major Collender was suspicious to the Indians. Since during these twenty years, he has not heard something true from them. According to him, the Indians have desire to please at the cost of being insincere, but they are doublefaced. Forster as an English author exaggerates the Indians' deficiency as S. R. Moosavinia generally believes, "There is no doubt that Forster has exposed the malicious attitudes of the British in his novel" (2011, p.70).There are some contradictions in Dr. Aziz's manners: he wears tie, collar stud, and suit, at the same time he seems oriental. Jajja in his article concludes that "Dr. Aziz is Forster's version of an Indian, who in reality lives in the past and retires to a native state and composes poems about bulbuls and roses. At the end he makes his peace with the English" (2013, p.47). When he wants to give his patients some drugs, he mixes some magic with them while he is a capable doctor. $\mathrm{He}$ is a devotee to the memory of his wife, but while visiting Mr. Fielding, he shows the photo of his wife to him as a sign of intimacy and brotherhood. His action is uncommon among Moslems who believe in Purdah - a system of keeping women out of public view, as Jajja criticizes his action, "The Oriental fool Aziz, cannot see the difference between hospitality and intimacy" (2013, p.44).

Dr. Aziz is a very decisive person, but at the same time he is moody, impulsive, and unpunctual. He invites some body to his home, but very soon he changes his idea. To Forster, in general, the Indians are instable and dishonest; and hospitable at the 
cost of being insincere.In chapter nine, when Dr. Aziz falls sick, and everyone goes to visit him, Godebole also accidentally falls sick. Their coincident illnesses makes Major Collender mistrust them.

\section{THE IMPOSSIBILITY OF UNITY, ANTI-} THESIS

\section{A. ACCIDENT}

On the way towards the Marabar Caves, the group had an accident, but each of the members of that group mentioned something different from the others' reason as the culprit of the accident. Adela believed the accident happened due to a wild animal like a buffalo in darkness. Navab Bahador said it was because of a ghost, Ronny thought it was due to a hyena, and the rest attributed the accident to some supernatural earthy causes. Forster criticizes them as knowledgeable people who lack harmony upon the reason of one simple accident.

\section{B. THE MARABAR CAVES, ECHO, CHAOS, MYSTRY}

According to S. R. Moosavinia, "E. M. Forster's Marabar Caves in A Passage to India reflect India as an object of non-comprehension" (2011, p.72). In chapter ten, the weather is too hot, representing the oppressive atmosphere of India. Up until this chapter, the weather was cold, and there was the possibility of communication and development of unity, but by hot weather and by what happens inside the Caves (echo, chaos, and mystery) this possibility is destroyed. Adela Quested, as her name signifies her aim for a search of peace of mind and ease of heart, has come to India to marry Ronny. However, Ronny is not the person she expected. She does not enjoy mystery and muddles of the Marabar Caves. Her mind is obsessed by Ronny's physical love, so this pessimistic view and psychological obsession of marriage makes her think Dr. Aziz would try to rape her in the Caves. Indeed, Adela projected he feelings of guilt on the innocent Dr. Aziz. She charged him with rape because she had become aware that her future union with Ronny without any self-esteem or love would be nothing else but rape. The first echo of evil which hunted Adela in the Caves makes her deluded to experience symbolically the utmost degradation of a union without love. Her feelings of guilt and disappointment shatter her personality and create a delusion in her. The discovery does not happen to her, unless this contradiction can be solved. What happens to her inside the Caves is to be explained not on the basis of any actual event, but in terms of her own state of mind.

However, the second echo at the court, the Indians' echo of Mrs. Moore's name, as if they call a goddess for salvation, helps Adela become free from her delusion and change her story saying Dr. Aziz was innocent. Therefore, the echo acts in two folds: one echo, inside the Caves, distorts her balance, and the other echo, at the court, restores her to the truth and reality. The reader perceives that the Caves, similarly offer a symbol which works on two levels: the former is the negative meaning of the Caves, symbolically the unavoidable evil, and the latter stands for the power of reconciling and intimation.In chapter seven Godebole sings a song to Krishnas, God will never come. Godbole knows the myth of the Caves, but he prefers people themselves to experience it. Godbole is a Hindu and he believes in myth, but Dr. Aziz is a Moslem and he cannot accept Hindu's belief of myth. Again the novel denies the possibility of oneness, and takes the state of suspense.In chapter twelve, we have the concept of Siva, a god that creates and destroys, emphasizing the ancientness and mysteriousness of India. "The Ganges, though flowing from the foot of Vishnu and through Siva's hair, is not an ancient stream" (Forster, 1985, p.123).Man's knowledge is unable to understand the mystery of the Marabar Caves that is the reason why everybody who comes out of the Caves gets dumbstruck. The images of horror, dullness appear right after the description of the Caves. For Forster these caves are "Extraordinary" because the only thing they offer is nothing. After coming out of the Caves, the people's way of looking changes. All of a sudden, they are awakened by a force and the harshness of life. Now, they are capable to see the stones and the snake to which they were already blind. "Inside its cocoon of work on social obligation, the human spirit slumbers for the most part, registering the distinction between pleasure and pain, but not nearly as alert as we pretend" (Forster, 1985, p.132).

\section{TEMPLE, PARTIAL UNITY, SYNTHESIS}

The temple section of this novel provides us with the vision of a partial reconciliation. This vision dissolves the artificial human barriers created in the earlier parts of the novel. In this part, we find that 
the spirit of Mrs. Moore and the spirit of Hinduism begin to work together to arrive at spiritual unity and oneness. When these two friends, Dr. Aziz, and Mr. Fielding take their last ride together, they speak frankly. Dr. Aziz believes they can be friends if and only if the English leave India. Therefore, we have the same paradoxical notion of friendship in separation. At the end of the novel when Mr. Fielding criticizes the Indians, seeking to establish a unified nation in vague, by referring to their different religions and cults: Indians, Moslems, Hindus... indeed he takes advantage of this apparent disintegration to conclude that any other kind of unity and consolidation also is impossible to them, while he is oblivious to Nehru's phrase, "unity in diversity" as an Indian slogan, or Sahitya Akademi's line, "Indian literature is one, though written in many languages" (Ramanujan, 1989, p.42). Moosavinia believes that Forster has "manipulated the point of view in a way to suspend any type of finality and to demonstrate" (2011, p.78), as it is argued in Armstrong's article, "Reading India: E. M. Forster and the politics of interpretation", "the difficulty (perhaps impossibility) of attaining a lasting consensus about any matter or of discovering a final, uncontestable meaning to any state of affairs (Armstrong, 1992, p.367, as cited in Moosavinia, 2011, p.78). Armstrong has suggested that "it is impossible to reach a consensus about truth and justice, and that different perspectives have the right to pursue their own particular visions" (Armstrong, 1992, p.382, as cited in Mossavinia, 2011, pp.78-79). This statement sounds contradictory. It negates itself as we find the same problem with "deconstruction". One feels that the writer has invited us for "a game in the novel where the reader experiences invoking and negating at the same time, to suspect ideals one believes and believe ideals one suspects" (Moosavinia, 2011, p.79). Therefore, Forster's A Passage to India is "contrapuntally read by Said as 'evasive and more patronizing"' (Said, 1993, p. 246, as cited in Moosavinia, 2011, p. 80).The third part, temple, also signifies a unity because of three important scenes: the scene of birth of Shrikrishna, the scene where the two boats (of Dr. Aziz and Mr. Fielding) collided making another reconciliation, and the last scene as the last ride Dr. Aziz and Mr. Fielding take together when finally they go to their separate ways in order to remain friends. It seems that people from different cultures rarely understand one another. As Abu Baker argues in his article, "Rethinking Identity: The Colonizer in E. M. Forster's A Passage to India", Forster himself explains his dual intention in writing the novel. In a letter he states that:

When I began the book I thought of it as a little bridge of sympathy between East and West, but this conception has had to go, my sense of truth forbids anything so comfortable. I think that most Indians, like most English people, are shits, and I am not interested whether they sympathize with one another or not" (Forster, 1985, 15, as cited in Abu Baker, 2006, p.69).Such duality and confusion happen to the other characters. Fielding, for instance, declares his love for the Indians. "I have never felt more happy and secure out here. I really do get on with Indians, and they do trust me" (Forster, 1985, p.261). Yet, according to Abu Baker, "he cannot get over his racial superiority complex. He feels the presence of this 'fundamental difference"' (2006, p.80). Furthermore, Fielding tries to convince Dr. Aziz of impossibility of India ever becoming a free and united nation while it has different religions and cults. Still their last kissing while undermining any possibility of unity, and independency leaves the reader in doubt, to what extend we can count on their friendship or hostility.

\section{CONCLUSIONS}

The novel is divided into three parts, three Indian seasons. In the first part we have the concepts of mosque, Moslems, good (cold) weather, stability of mind, and arch. Therefore, we have the possibility of unity and communication between the English and the Indians. However, in the mosque, an ambiguous triumph of Islam is implied in the form of ironic duality of colors In the second part, we have the Caves, symbolizing chaos, confusion (muddle), echo, hot weather, and mystery; consequently, the complete collapse of unity and annihilation. Heat is a common symbol of irrationality and instability of the people under the force of nature they cannot stop. India's hostility to its colonizers is demonstrated in the heat, which becomes so problematic to the English.Finally, in the third part we have the notion of temple, Hinduism, the rains, and sky, so the concept of unity is partially revived. The temple corresponds to the rains and Hindu elements, so it implies that 


\section{A Symbolic Deconstructed Colonialism}

human relationship is possible but it is always on the verge of collapse.A Passage to India, according to Jajja is somewhat "an optimistic novel" (2013, p.47). Jajja argues that the Indians are presented as "superstitious, diffident, irrational and excitable" (ibid, p.48). Forster believes that this relationship between empire and India can continue, even if cripplingly. These three divisions of the novel, three Indian seasons, demonstrate a kind of Hegelian Paradigm, thesis, anti-thesis, and synthesis. Forster does not offer any crystal clear relationship. Each time we tend to believe that such oneness is about to be established, due to some occasions this chance is delayed, and the novel leaves us frustrated and denies any reconciliations between the nations. This unity is for so many reasons next to impossible.

In contrast to the Romantic Walt Whitman's "The Passage to India" that is about a spiritual passage of a man wanting to be brought face to face with reality, Forster seems to say the Indian spirit is mingled with mystery; thus those who cannot understand the spirit of India, cannot in one way or another understand the reality of it.

\section{References}

Abu Baker, Ahmad M. S. 2006. Rethinking Identity: The Colonizer in E. M. Forster's A Passage to India. Nebula, 3.2-3, 68-85.

Forster, E. M. 1985. A Passage to India. Cambridge: Penguin Classics.

Jajja, Mohammad Ayub. 2013. A Passage to India: The Colonial Discourse and the Representation of India and Indians as Stereotypes. Gomal University Journal of Research, 29(1), 38-48.
Forster's India is hostile to foreigners and attacks its colonizers ferociously, so as to force them to leave. Despite the British attempts to 'tame' India, it remains a 'wild' country. "The destiny of the English seems to resemble their predecessors', who also entered the country with intent to refashion it, but were in the end worked into its pattern and covered with its dust" (Forster, 1985, p.215, as cited in Abu Baker, 2006, p.70). As Abu Baker concludes, "India refuses to give a sense of home to its colonizers". Hence, they remain in "exile". Indeed, "India makes sure that no colonizer can call it home" (2006, p.70). The English and the Indians can become "more intimate, but the problems of cultural differences, stereotyping, and colonization prevent the possibility of having a real friendship between them" (ibid, p.73).Still the basic question that the novel has begun with remains unanswered, "Can the actual reconciliation be made between the English and the Indians"? Each time we begin to admit an opportunity of integration and unity, this chance is immediately delayed or harshly denied.

Kundu, Rama. 2008. India through British Eyes in E. M. Forster's A Passage to India. 32-37.

Moosavinia, S. R. 2011. Texts and Politics: Postcolonial Revaluations of two British Classics. The Journal of Teaching Language Skills, 64(4), 67-82.

Ramanujan, A. K. 1989. Is there an Indian way of thinking? An informal essay. Contribution to Indian Sociology. 23(1), 40-58. 